\title{
Research on the Connotation and Forming Factors of University Running Characteristics
}

\author{
Xing-Hua LU ${ }^{1, a,}{ }^{*}$, Zhi-Xin MA ${ }^{1, b}$ \\ ${ }^{1}$ Army Engineering University-Shijiazhuang Campus, China \\ alu-xh163@163.com , b907229834@qq.com
}

Keywords: University, Higher Education, University Running Characteristics, University Running Idea.

\begin{abstract}
This paper analyzes the necessity of establishing the university running characteristics, expounds the concept and connotation of the university running characteristics, and studies five forms of expression of the university running characteristics. Lastly, this paper puts forward the basic law and the key elements of the establishing the university running characteristics.
\end{abstract}

\section{The proposing of the university running characteristics problems}

The proposing of the university running characteristics problems began in the western developed countries such as the United States. At the beginning of last century, with the vigorous development of higher education such as the United States and some other Western powers, university education began to popularize. However, the developed higher education provides more educational opportunities and choices for the educated, but also brings crisis to its own development. Because many universities' educational function is blurring, the idea of running a school is not clear, the orientation of running a school is not accurate and the direction of development is not prominent, it leads to mutual imitation, blind development and lack of individuality among universities. This problem has caused quite a number of universities to lose their attractiveness and development power, especially during the Great Depression in the 1920s, many universities had a survival crisis. Facing this situation, some university leaders begin to realize that the development of the university needs to go out of the "ivory tower", closely related to the social development needs. On the other hand, it is necessary to find the orientation, carry out differential development and form a unique personality so as to obtain the development motive force, maintain the development vitality and form the competitive advantage. Under the guidance of this idea, many universities began to seek personalized and differentiated development. Especially in the 1930s and 1940s of the last century, the American higher education circles set off an upsurge of formulating the strategic planning of the University. Through the formulation and implementation of the differential strategic planning, the university has made great efforts to promote individualized development, as a result, a large number of colleges and universities have gained vitality for development and quickly become a first-class international university with distinctive features. It can be said that the distinctive characteristics of running a school have become a common external characteristic and value expression of the world's leading universities and famous universities.

China's attention to the issue of university running characteristics began in the 1990s. With the deepening of China's reform and opening up, China's higher education has entered a period 
of great development. Many public colleges and universities “upgraded”, “amalgamated” and expanded their scale, and private universities have sprung up like bamboo shoots after the rain. The great development of higher education has promoted the popularization of higher education. At the same time, it also brings fierce competition in the student sources and education resources in Colleges and universities. This competition quickly shifted from the contention of the scale of college and the student sources to the contention of the college brand, and people began to pay more attention to the quality, characteristics and Social recognition degree of university. In order to effectively promote the improvement of the overall level of Chinese higher education and university individualized development, to avoid the emergence of the university convergence problem, the Ministry of National Education of China put forward clearly for the first time in "The Outline of China's Education Reform and Development (1993)" that We should pay attention to building and cultivating the university running characteristics. Since 2003, "the university running characteristics project" are included in the national undergraduate education evaluation scheme, which has aroused general concern and attention to the university running characteristics problem.

\section{The concept and connotation of the university running characteristics}

At present, there is no a universally accepted to definition of the university running characteristics in academia. In the western countries, the literature on the characteristics of school running is very limited, but from the educational monographs and related comments of some famous western educationists or famous university presidents, it can clearly see their understanding and pursuit about the university running characteristics and the university running personality. Prof. Alison Richard, the president of the University of Cambridge, once said that in the whole higher education system, every university has its own characteristics, and the pattern of diversification is the external manifestation of every university. Prof. Ishi Hiromitsu, the president of the Hitotsubashi University in Japan, believes that universities with no characteristics or personality are difficult to base on society when their scale development is blocked. The president of David Baltimore, California Institute of Technology, proposed that universities should have a variety of types and levels. Schools of different types and levels have their own characteristics. The most important thing is to make clear orientation, to clear ideas, to keep their features, and to innovate constantly, to become a first-class university.

In recent years, with the increasing emphasis on the characteristics of running schools in China's higher education circles, relevant research has also presented a high degree of "heat." This has played a positive role in the profound understanding the nature and significance of the university running characteristics. For the definition of university running characteristics, many Chinese scholars have elaborated on them from different perspectives. At present, a relatively wide identification definition is given in the "Research Report on University Running Characteristics Issues" by the Chinese and Foreign University Presidents Forum in 2002, that is, "the university running characteristics refer to a relatively durable and stable development mode formed by a university in the course of development and socially-recognized, unique and excellent school-running feature. Starting from this definition, many scholars have made a deep study on the connotation of university running characteristics, and think that the connotation of university running characteristics is mainly reflected in six aspects.

(1) Uniqueness. Uniqueness means having a difference from other colleges and universities in the same aspect or the same field, it is the particularity built on the basis of universality. The 
uniqueness can be understood from two aspects. One is "independence", that is unique, which is what people usually say " other one have not and but only I have"; the second is "special", which is a significant difference or personality when compared with similar things. This difference or personality can be a whole or a certain aspect, but it must be easy for people to identify and perceive.

(2) High quality. The high quality of the university running characteristics is superior to those of similar universities. Advantages are not characteristics, but they can be transformed into characteristics under certain conditions. Compared with uniqueness, only when a university's uniqueness has the advantage that other universities cannot catch up and be no able to manage in a short period of time, can this constitute an advantage of a university. Therefore, the lack of uniqueness cannot form the university running characteristics, and there is no absolute comparative advantage that cannot be the university running characteristics.

(3) Public recognition. Whether a university is good or bad, and whether it has the characteristics of running a school, its own recognition is not "authoritative". Only when a university is widely recognized by the society, its characteristics of running a school can really be established. Because the evaluation subject of the university running characteristics is not entirely university own, but is the object of its service or a third party, relying on its own “tagging” can only be self-deception and unconvincing.

(4) Stability. The formation of the university running characteristics requires a process of long-term cultivation and gradual accumulation. Once the characteristics of running a school are established, it should be relatively stability in a certain period of time, and will not be flash in the pan because of some interference or some conditions. The reason why this is so is that the formation of the university running characteristics is not only the accumulation of material conditions, but more importantly, it forms a solid idea and traditional style. This is the fundamental reason for the stability of the university running characteristics.

(5) Development. The stability of the university running characteristics is a relatively stable situation, but it is by no means solid, rigid and always unchanged. If establishing the university running characteristics is a development strategy of a university, the formation of the university running characteristics is actually a form of development mode. Therefore, keeping pace with the times and developing independently are not only an external style of the university running characteristics, but also an internal driving force for development.

(6) Diversity. The university is a complex system, which includes a lot of disciplines and a large number of school elements and resources, which creates conditions and possibilities for different universities to choose different ways of development. The university is also an open system, it gains development opportunities and energy by exchanging information and resources with the outside world. This state of university will inevitably make the development of the university multi-dimensional and open, and therefore, the university running characteristics should also be diversified, this also provides possibility for the uniqueness of the university running characteristics.

\section{Manifestations of the university running characteristics}

Some scholars have analyzed the characteristics of school running for 150 universities in China. Through the study, we can see that the current university running characteristics are mainly reflected in five aspects, that is, the characteristics of university running idea, the 
university spirit characteristics, the characteristics of discipline and specialty, the characteristics of training talents mode, and the talent characteristics.

\section{The characteristics of university running idea}

Idea is an abstract generalization of people's ideology, spiritual yearning, ideal pursuit and philosophical belief formed through long-term rational thinking and practice. The idea of running a university is the height summarization of a university leader's idea of running a school and the strategy of running a school, and it is a deep thinking about "what kind of university is to be established," and "how to run a good university". Looking at the history of the development of the world's first class universities, we can see that all the world class universities have a distinctive idea of running school without exception, this idea of running schools is closely related to the thought of running school for university principals, and their the university running characteristics are often formed under the guidance of the school principals' unique idea of running a school. Mr. Huang Boyun, president of the Central South University, pointed out: "the university running idea is the soul of the university, and is cognitive foundation about what kind of university is to be established, how to form the characteristics of running a school, and how to run a good university. And there is what kind of the university running idea. There is what kind of the university running characteristics, it will have what kind of school characteristics and educational innovation. The idea of "pursuing academic" has led Oxford University to lead a coquettish for hundreds of years; the idea of "unification of teaching and research" has led Humboldt University to lead the trend of higher education reform in the world; the idea of "serving the society" has made the University of Wisconsin a banner for the development of higher education. A large number of facts show that university innovation is first of all the innovation of university running idea, only by innovating the idea of running a school can we create a distinctive University. The university running idea has a guiding and inspiring function, and it is the inner spiritual power and motive force of running a scholar. At the same time, the university running idea has a macro-normalization, once the university running idea characteristic is formed, it can make the school go down the existing road, resist the disturbance of the outside world, and keep the characteristics. Mr. Neil Rudenstine, the president of Harvard University, said, "the success of Harvard University is mainly forming a clear the university running idea, a set of systematic regulations and mechanism, so even if there is no headmaster now, Harvard University can operate normally."

\section{The university spirit characteristics}

University spirit is a unique and stable ideal, belief, values and code of conduct, which is recognized by university teachers and students and is formed in the process of running a university, it is the soul of the university running characteristics. University spirit is intangible, but it is perceivable. The university spirit is first of all a philosophical concept, and reflects the unique philosophical thoughts of a school. It is essentially the philosophical abstraction of the university running idea, the policy of educating people, the academic pursuit, and the management model, and is the integration, refinement and distillation to the ideology of "cultural body" and "cultural group" in the university. The university spirit is also a historical concept. It was not created overnight, nor is it the product of the mind of any principal or master. It is formed through long-term historical precipitation, cohesion, and development. It is the natural result of value judgments, value choices, and value recognition in a particular range of "cultural bodies" and "cultural groups". From the history of the development of some famous 
universities in the world, some famous universities to maintain a strong "vitality” in a long time, it is a very important point that these universities have maintained their own unique spiritual character for a long period of time. For example, Harvard University's spirit of "being friends with truth", University of Chicago's "experimental attitude, advocating truth-seeking" scientific spirit, and so on. In the spirit of the university, we can not only see the historical footprints of the school, but also see its actual pursuit. We can not only see its fine traditions, but also see the fruits of its innovation and feel its Spiritual pulse for advancing with the times.

\section{The characteristics of training talents mode}

The characteristics of training talents mode refers to certain special training methods adopted in the process of personnel training to achieve training objectives under the guidance of certain educational thoughts and theories, and has gradually formed a certain style or characteristics. The talent training mode embodies the educational ideas and educational thoughts held by university-run scholars on the objectives and training methods of talent training, and is a specific practice on how to training talents. For different universities, due to the differences in the orientation of running a school, the idea of running a school, the guidance of running a school, and the resource of running a school, especially there are differences in the cognition of talents training objectives and training laws, and it will inevitably take different approaches to talents training, thus forming different characteristics of talents training mode. In recent years, with the rapid development of science and technology and the general improvement of the demand for high-quality innovative talents in all fields of society, the innovation of talent training mode has become the focus of many university education reforms, and has gradually explored and formed a number of different distinctive characteristic of talent training mode. Only when modern universities really find the talents training model which is fit and effective with the goal of talent training, and they can deliver a large number of talents with their own characteristics for the society, their the quality of running a school can be recognized by the society, and the university really takes the road of characteristic development and sustainable development.

\section{The characteristics of discipline and specialty}

In higher education, the discipline and specialty is a Subject category according to the needs of the social professional division of labor and the internal logic of the discipline system, it is the basic unit of the university talent training and the interface with society. The discipline and specialty has a fundamental and overall impact on the development of the university, the construction of the discipline and specialty fundamentally reflects the level of running a university and the characteristics of running a university, it is the most important brand of a university and the prerequisite and foundation for the survival of a university. It is impossible for any university to make all disciplines occupy academic commanding point, even the famous disciplines of the world's famous universities are famous for their unique achievements in the disciplines. Therefore, to build a characteristic university, it is necessary to put the characteristic discipline and specialty in an important strategic position, and take the characteristic discipline and specialty as the leader of the university development, so as to drive the comprehensive construction of the university. 


\section{The talent characteristics}

The so-called talent characteristics usually refer to what the trained talents have the distinguishing feature or idiosyncrasy. This characteristics is mainly the unity of talents' uniqueness, autonomy and creativity. Talents (students) are the core products of a university, and the characteristics of talents are the fundamental foundation of university characteristics. A university can train students with distinctive characteristics and recognized by society, that this university has the most distinctive characteristics. The reason why Oxford University is praised by people is that it is not because of its long history, but because its faculty is first-class and the students it cultivates are first class. The reason why the United States Military Academy at West Point is known both at home and abroad is that since its establishment in 1802, the West Point Military Academy has trained two presidents, four five-star generals, and 3,700 generals. Among the top executives in the world's top 500 companies after World War II, there are more than 1,000 presidents, more than 2,000 vice-chairmen and more than 5,000 general managers came from West Point and none of the nation'sbusiness schools have trained so many elites in management. In China, people admire Peking University and Tsinghua University because they have become the cradles of our country's politicians and top scholars.

The above five aspects of the university running characteristics are not separated from each other, but are interrelated and mutually restrictive, and there is an inevitable logical connection between each other, as shown in Figure 1.

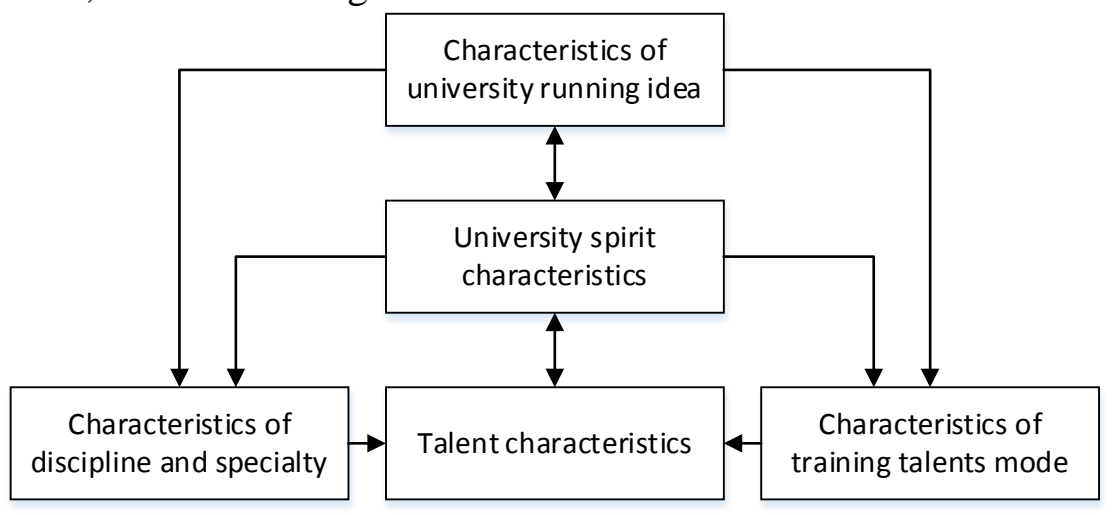

Figure 1. The logical relation diagram of 5 kinds of university running.

\section{The core elements of forming university running characteristics}

The university is a purposeful open system. The formation of the university running characteristics cannot be spontaneous or naturally formed, but it needs to be purposeful planning and designed at a certain stage in the development of the University, through the orientation, goal, and path of the development of the university, and gradually formed after continuous efforts. Among these, four key factors are very important for the formation of the university running characteristics.

\section{The outstanding university president}

If the university is likened to a ship, the president of the university is the captain of the ship, his status and role determine the course and goal of the ship. From the perspective of all the distinctive universities in the world, the formation of their university running characteristics is closely related to one or more outstanding principals in the history of the university. For 
example, Harvard University's Charles William Eliot(1869-1909), Abbott Lawrence Lowell(1909-1933), J-B-Conant(1933-1953) and Derek Curtis Bok(1971-1991, 2006-2007); MIT's William Barton Rogers(1861-1870,1879-1881), Karl Taylor Compton(1930-1948) and James Rhyne Killian(1948-1959);Wilhelm von Humboldt, Johann Gottlieb Fichte and F. E. D. Schleiermacher of the University of Berlin; Cai Yuanpei of Peking University, Mei Yiqi of Tsinghua University and so on. The common good qualities of these principals have played a vital role in the formation of university running characteristics. In the university development, they all have a unique running a school idea, which directly affects the direction of running a university, the orientation of running a university, the function of a university, the role of a university, and the determination of university tasks. In the management of universities, they observe opportunity to carry out deep reforms and innovations with long-term pursuit and ambition of university development. In the treatment of talents, they attach importance to the role of great masters, are good at attracting outstanding talents, and create an academic ecological environment with great masters as the core, thus they have led a number of disciplines and colleges to gradually form the advantages of running a school, thus making the university with different characteristics. In their personal qualities, they have the spirit of being first in the world, and they can concentrate a lot of time on their main actions and are not obstructed by the initial failure. Therefore, outstanding principals are the most critical factor for the formation of university running characteristics.

\section{The accurate orientation of development}

Characteristics are a kind of comparative advantage. "Other one have not and but only I have" is a characteristics, "other people have but I'm stronger" is a characteristics, and "others are strong but I have new" is also a characteristics. To establish characteristics, one of the important aspects is to establish its characteristics in a certain scope or type. Generally speaking, in the higher education system, the types and levels of higher education institutions differ greatly, the university running characteristics is characteristics or comparative advantages at the same type and level, has a position in the development and competition, which will form a "location ". The advantages and characteristics are both the advantages and characteristics of the "location", departed from the "location ", advantages and characteristics do not necessarily exist. Therefore, to establish the characteristics of the school, we must have a correct understanding of the nature and type of the university, and have an accurate positioning and find its own "location", and on this basis, the university running characteristics is discovered, and build, and strengthened.

\section{Forward-looking the idea of running a school}

Whether a university has its own characteristics is concentrated on whether the idea and thought of running a school have own distinctive characteristics. The idea of running a school is a whole set of thoughts and ideas that is related to what kind of university idea as a guide and how to realize the university idea, it play a commander role in the development of the school. From the view of the development of Chinese and foreign universities, to establish a distinctive characteristic the ideas and thought of running a school, is it necessary to grasp the trends of economic and social development and higher education reform in a certain period, and to accurately analyze the historical conditions and background of school survival and development, and to seize the historical opportunity, break old rules, innovate boldly, and dare to be the first. In the short 35 years course of running a school, Warwick University of Britain can leap into the top 10 universities in the UK and enter the ranks of the world famous high 
level universities, one of the important reasons is to make bold innovation in school running ideas, to get rid of the traditional school running mode and to adhere to the road of characteristic, and it has formed a situation of emphasizing the overall interests of the school, expanding the scope of service, implementing the school running strategy of pursuing the unification of academic excellence and economic benefits, and strengthening scientific research and extensive relations with industry and business.

\section{The construction of characteristics discipline and specialty}

The university functions of talent training, scientific research, and social services are all based on disciplines and specialties, leaving the discipline and specialty construction, talent training, scientific research, and social services will become passive waters, wood without roots. Therefore, the construction of high level and distinctive disciplines and disciplines can effectively promote the comprehensive development of the university, and drive the whole university to a higher level. In the final analysis, the competition among universities is the competition between the level of disciplines and specialties. The strong and the weak of universities is usually shown through comparison of disciplines and specialties. So, strengthening the discipline and specialty construction of universities is the core task and the top priority of university development. It should be noted that in the construction of disciplines, it is necessary to highlight the construction of key and predominant disciplines and specialty, and at the same time, we must not neglect the construction of other related disciplines and specialties, especially we must pay attention to make up for the vacancies in the disciplines and specialties structure so that the disciplines and specialties can form mutual support and the internal structural relationship that promotes each other, this is also an important link in the construction of disciplines and specialties. In addition, in the construction of disciplines and specialties, it must also examine the needs of society, the needs of the market and the need of the talents training, and must put all kinds of needs on a balance of rationality, and correctly handle the relationship between "cold door" and "hot door ", "sunrise" and "sunset", so as to make those the characteristic disciplines and specialties have been developed in accordance with social needs.

\section{Conclusion}

The university running characteristic is the foundation for the existence and development of a university, and is one of the goals that any university should pursue. The university running characteristics cannot be formed naturally, nor can they be "built" in a hurry, but must follow the basic rules of the university running characteristic construction. And after a university enter a benign operation and has a good foundation, the universities can only begin to pay attention to the university running characteristics and start with the elements to take a variety of measures to actively cultivate it. The construction of university running characteristics is a development process from quantitative change to qualitative change and from low-level to high-level development, and has only starting points and no end points, and must be in a persistent way and effort in step by step to achieve significant results. The characteristic development is a development strategy that any university should uphold. Once the characteristics of running a school are established, it will become an advantage of the university, a valuable educational resource and a hidden "university culture", and make the university have a strong core competitiveness in the fierce competition. 


\section{References}

[1] Shang Gang. Theoretical Thinking on the Construction of University Running Characteristics [J]. Higher Engineering Education Research. 2008, (2):100-103.

[2] Zhao Limin. Research on the Elements of School Running Characteristics [J]. Journal of Tianjin Normal University, 2011, 218 (5): 76-80.

[3] Guo Yi, Li Zhihong. The Main Manifestation and Formation Law of University Running Characteristics [J]. Chinese Higher Education, 2011, (1): 39-41.

[4] Higher Education and Teaching Evaluation Center of the Ministry of Education. The "School Running Characteristics" of Colleges and Universities [J]. Teaching in Chinese Universities, 2006, 9 (15): 10-15.

[5] Huang Boyun. Characteristics Development: the Idea of Running A University [J]. Modern University Education, 2003, 1 (2): 31-33.

[6] Report on the Formation and Development of University Running Characteristics Submitted by Chinese and Foreign University Presidents Forum in 2002 [J]. Journal of the National Institute of Education Administration, 2003, (3): 17-23

[7] Li Yuping. Forming the Characteristics of Running Schools Is the Direction of the Construction and Development of Universities. [J]. Adult Education in China, 2007, 1 (2): 13-16.

[8] Chen Cuirong. Reflection and Construction: Research on the University Running Characteristics [D]. Wuhan: Huazhong Normal University, 2007.

[9] Zhou Xuan. The Characteristic Development Strategy of Harvard University [D]. Wuhan: Wuhan University of Technology, 2008.

[10]Wang Qiang, Cong Guangnian. School Running Characteristics of West Point [J]. Comparative Education Research. 2011, (6): 60-65. 